like acts of policy than historical necessities. Second, not all the talk of the need to reorganize research expenditure in Britain has yet touched the question of how policy on defence research should be worked out. Third, there is a danger that enquiry into the management of research policy will become a substitute for policy. In the past ten years, there has been a continual struggle by the government and its advisers to optimize the mechanism for dealing with research in Britain. It is entirely possible that the time has come to leave it alone for a while.

\title{
Technology Assessment has a Long Am
}

THE ministers for science from the member nations of the OECD seem to have had a useful meeting in Paris last week and, although these representatives of European governments are still shadow-boxing with each other as becomes political intervention in a dangerous field, they seem now to have got the hang of how to make a public statement of policy. The hope is that they will soon also learn how to make effective policies, for there is an urgent need that some means should be found of giving the OECD a framework within which to do sensible things.

The difficulty with last week's meeting was the concept of technology assessment (see page 512), invented originally by Mr Harvey Brooks of Harvard University. The trouble is that technology assessment is too seductive a concept for politicians to resist. The phrase itself implies two things - solicitude for technology and anxiety that the consequences of technology should be predicted. In other words, technology assessment appeals both to technologists and to those who are suspicious of technology. At the meeting in Paris last week, the ministers appear to have applauded themselves for devising a communiqué that says such things as "more basic knowledge is necessary to solve the increasingly complicated problems of modern society", which holds that "the growing importance of social objectives requires increased support for the relevant social sciences, including research" and at which ministers are said to have "agreed on the need to stimulate further improvements in the innovation process if the results of research and development are to have the maximum diffusion in society". It is true that the spirit of a successful conference is rarely embodied in the communiqué issued at the end, but on this occasion platitude seems to have had a field day.

What should the ministers of the OECD do ? It is not, after all, that there are no jobs to be tackled. It is tempting to think that a call for "intensified scientific and technical cooperation" will serve some purpose, but how is the cooperation to be carried out, in what fields, by whom, and which governments will take the initiative? It is tempting to think that outsiders will be stimulated by the declaration that "a major task for science policy will be to assess the adverse and beneficial consequences of technological development and to foresee scientific and technical trends", but who are the people who will also foresee the consequences of now familiar practices, such as the dumping of untreated sewage into freshwater lakes and rivers? Which governments will accept the logic of those discoveries and require their taxpayers to provide sewage treatment plants? The trouble is that technology assessment is not merely a balm for the consciences of those who think that technology needs watching but a defence for those who hope that, if enough people worry about problems which do not yet exist, nothing need be done to tackle the problems which already abound.

\section{Whose Head is in the Sand?}

A WEEK from now, it should be apparent whether or not Britain will be joining the European Communities in 1973. The debate now under way in the House of Commons will finish on Thursday with a vote that will decide whether the British government is strong enough politically to go ahead with its intentions to accept membership on the terms which have been negotiated, at least in outline, over the past few months. It is shrewd of Mr Edward Heath, the Prime Minister, to have said that members of his own party will be allowed to vote as their inclinations guide them. He has very little to lose and quite a lot to gain by taking this course. Even so, the outcome of the proceedings in the House of Commons remains uncertain. Mr Heath will get his majority, but it remains to be seen how large it is or, perhaps more important, how it is constructed and thus how strong it will appear to outsiders. This is why it may not be entirely out of place to recall that the present difficulty about British membership of the European Communities stems almost entirely from the way in which the leadership of the British Labour Party, with one or two exceptions, has gone back on its own commitment to membership.

The shabby way in which this has been done is a conspicuous scandal. There is at present no reason to suppose that Mr Harold Wilson's government would have been able to negotiate better terms for membership than those agreed last summer in Brussels, and no reason to expect that the previous Labour government would not have accepted them. The argument which now prevails that the terms could have been better is hard to deny, but to use this complaint as a serious criticism of the arrangements now proposed is a little like the way in which would-be members of golf clubs might complain that they will join only if the annual subscription is made cheaper. It is equally unconvincing now to complain that the policies of the European Communities will prevent the British government from pursuing its own schemes for regional development and the like and will thus infringe British sovereignty-for one thing, there has never been any doubt that the Treaty of Rome would inhibit the 